\title{
Environmental Control of Garlic Growth and Florogenesis
}

\author{
Rina Kamenetsky 1 \\ Department of Ornamental Horticulture, ARO, the Volcani Center, P.O. Box 6, Bet Dagan 50250, Israel \\ Idit London Shafir \\ The Hebrew University of Jerusalem, Faculty of Agricultural, Food and Environmental Quality Sciences, \\ Institute of Plant Science and Genetics in Agriculture, P.O. Box 12, Rehovot 76100, Israel \\ Hanita Zemah and Amalia Barzilay \\ Department of Ornamental Horticulture, ARO, the Volcani Center, P.O. Box 6, Bet Dagan 50250, Israel \\ H.D. Rabinowitch \\ The Hebrew University of Jerusalem, Faculty of Agricultural, Food and Environmental Quality Sciences, \\ Institute of Plant Science and Genetics in Agriculture, P.O. Box 12, Rehovot 76100, Israel
}

\begin{abstract}
AdDitional InDEX wORDS. Allium sativum, photoperiod, thermoperiod, fertility, floral development, topsets
Abstract. An understanding of temperature and photoperiod effect on garlic (A. sativum $\mathrm{L}$.) growth and florogenesis might solve the enigma of garlic sterility and provide environmental tools for flowering regulation and fertility restoration. The effect of storage temperature and growth conditions on the interactive relationships between the developing vegetative and reproductive organs was studied. A long photoperiod for more than 2 weeks was required for both dormancy induction of the axillary buds and clove formation. In contrast, combination of low temperatures with short photoperiod resulted in sprouting of the axillary buds. Four phases were recognized in the florogenesis of garlic, including: transition of the apical meristem, scape elongation, inflorescence differentiation, and completion of floral development. In garlic accession \#2091, meristem transition is autonomous and occurs in growing plants under a variety of storage and growth conditions. A long photoperiod triggers the initial elongation of the scape in post-transitional plants. The temperature effect was quantitative: low storage and growth temperatures combined with long photoperiod promoted scape elongation, whereas warm temperatures and long photoperiod promoted the translocation of reserves to the cloves, and the degeneration of the developing inflorescence. Differentiation of topsets followed flower formation and was dominated by and required lengthy exposure to long photoperiod. Hence, under short photoperiod with only short interruption of long photoperiod, normal development of fertile flowers occurred. We conclude that in bolting garlic genotypes, manipulation of the environment, both before and after planting, can regulate the development of flowers and regain fertility. Normal flowering cannot be achieved if any of the four developmental stages of florogenesis mentioned above is inhibited.
\end{abstract}

Garlic (Allium sativum L.) is usually sterile and propagated only asexually. Hence, increase in genetic variation has been possible only via random or induced mutations (Burba, 1993), somaclonal variation (Novak, 1990) or genetic transformation (Kondo et al., 2000). Restoration of sexual propagation in garlic is expected to facilitate the exchange of genetic traits from one genotype to another and to improve garlic cultivars via classical breeding. In addition, seed propagation of desired genotypes will reduce the cost of virus elimination, as well as reduce the damage caused by propagule transmitted diseases and pests, cost of storage, and loss of propagules during this phase.

The discovery of fertile plants in Central Asia in the 1980s (Etoh, 1986) brought the study of garlic flowering and seed production to the fore, and opened new avenues of research on genetics, physiology, and breeding. Garlic genotypes vary considerably in their ability to produce scapes, umbels, fertile pollen, and receptive stigmas (Etoh and Simon, 2002; Kamenetsky et al., 2003; Kamenetsky et al., 2004), but the genetic and physiological bases of these traits are unknown.

In garlic, the transition of the apical meristem from a vegetative to a reproductive state occurs during the active growing phase

Received for publication 2 June 2003. Accepted for publication 4 Nov. 2003. This study was performed in the framework of the EU project "Garlic and Health, The development of high quality garlic and its influence on biomarkers of atherosclerosis and cancer in humans for disease prevention" (QLK1-CT-1999-00498).

${ }^{1}$ Corresponding author.
(Kamenetsky and Rabinowitch,2001). Low temperatures promote floral development, and long photoperiod is essential for floral scape elongation (Takagi, 1990). It is rather common in garlic that after the initial development of floral buds, differentiation of topsets (inflorescence bulbils) begins in the peripheral part of the apical surface and proceeds towards the center of the umbel. The growing topsets intermingle with the young flower buds and cause their degeneration (Kamenetsky and Rabinowitch, 2001). The size of the topsets, their number, and their pace of development vary with genotype (Etoh, 1985, 1986; Kamenetsky et al., 2003; Keller, 2002). Fertility restoration in garlic has been attempted by many researchers (e.g., Etoh et al., 1988; Etoh and Simon, 2002; Kamenetsky et al., 2003, 2004; Kononkov, 1953; Konvicka, 1984; Novak and Havranek, 1975; Pooler and Simon, 1994), and sterility has been attributed to the presence of topsets in the inflorescence. Inaba et al. (1995), Jenderek (1998) and Kamenetsky et al. $(2003,2004)$ selected some fertile lines and obtained thousands of viable garlic seeds.

In all studied Allium species, environment plays a major role in florogenesis (Kamenetsky and Rabinowitch, 2002). However, the effect of the environment on garlic and the endogenous competition between its vegetative and reproductive developmental phases are far from clear (Brewster, 1994; Etoh and Simon, 2002; Kamenetsky and Rabinowitch, 2002; Pooler and Simon, 1993; Takagi, 1990), and more detailed study is required. Elucidation of the effects of temperature, during both storage and active growth, 
Table 1. Temperature and photoperiod treatments during the active growth of garlic plants in 2000-01 experiments. Before planting, bulbs were subjected to $60 \mathrm{~d}$ of constant storage temperatures of $-2,2,4,9$, or $20^{\circ} \mathrm{C}$. Short photoperiods $(\mathrm{SP})=10 \mathrm{~h}$ daylight; Long photoperiods $(\mathrm{LP})=10 \mathrm{~h}$ daylight followed by $10 \mathrm{~h}$ of incandescent light.

\begin{tabular}{lcc}
\hline $\begin{array}{l}\text { Initial period } \\
(60 \mathrm{~d})\end{array}$ & $\begin{array}{c}\text { Intermediate period } \\
(20 \mathrm{~d})\end{array}$ & $\begin{array}{c}\text { Final period } \\
\text { (until harvest) }\end{array}$ \\
\hline $17 / 9^{\circ} \mathrm{C} \mathrm{SP}$ & $17 / 9^{\circ} \mathrm{C} \mathrm{SP}$ & $17 / 9^{\circ} \mathrm{C} \mathrm{LP}$ \\
$17 / 9^{\circ} \mathrm{C} \mathrm{SP}$ & $20 / 12^{\circ} \mathrm{C} \mathrm{LP}$ & $23 / 15^{\circ} \mathrm{C} \mathrm{LP}$ \\
$20 / 12^{\circ} \mathrm{C} \mathrm{SP}$ & $23 / 15^{\circ} \mathrm{C} \mathrm{LP}$ & \\
$17 / 9^{\circ} \mathrm{C} \mathrm{SP}$ & $20 / 12^{\circ} \mathrm{C} \mathrm{SP}$ & $23 / 15^{\circ} \mathrm{C} \mathrm{SP}$ \\
Net house (ambient conditions & \\
\hline
\end{tabular}

Depicted in Fig. 1.
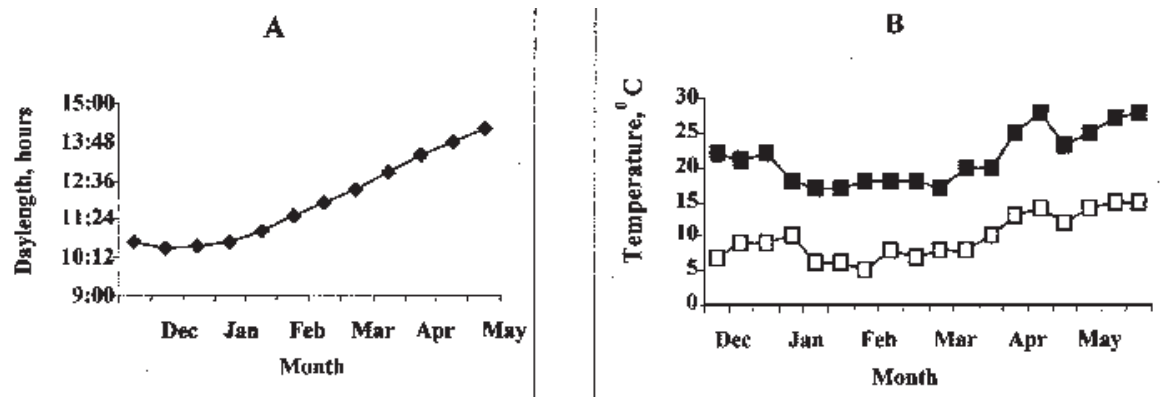

Fig. 1. Day length $(\mathbf{A})$ and weekly mean maximum and minimum temperatures

(B) in Bet Dagan, Israel, between December 2000 and May 2001.

and of photoperiod on the various stages of florogenesis may solve the enigma of flowering in garlic, and lead to the effective seed production.

The objective of this study was to determine the effects of temperature and photoperiod on the sequential morphological processes during the vegetative and reproductive development of bolting garlic.

\section{Materials and Methods}

Plant material. Garlic bulbs (accession \#2091, introduced to Israel from Russia in 1990), were received from the Field Gene Bank for Vegetatively Propagated Short-Day Allium spp., in Rehovot, Israel. The plant is adapted to short-intermediate days, and produces intact bulbs under Israeli spring conditions, annually. The experimental material was propagated vegetatively from a single bulb to guarantee genetic uniformity of the experimental stock. Mature bulbs were harvested, cured, and stored under ambient conditions, in an open shed. Before planting, bulbs were broken manually and individual cloves were inspected for biotic infection and for bruises. Medium-size, clean, healthy looking cloves were randomly sampled, treated with $0.2 \%$ Benlate (Du Pont De Nemours, France) and 1\% Marpan 50 wp (Machteshim, Israel), and planted in 1.8-L plastic pots containing a mixture of peat (RHP; Dega Potground Delft Company, Holland) and 0.8-mm volcanic tuff particles (Israel, Golan Heights) at 1:4 by volume. Experiments were performed at Bet Dagan (ARO, the Volcani Center). Standard phytotron fertilization consisted of $0.002 \%$ water diluted 'Shefer 1' liquid fertilizer $\left(\mathrm{N}: \mathrm{P}: \mathrm{K}=3: 5: 8 \mathrm{~g} \cdot \mathrm{L}^{-1}\right.$, Dshanim, Israel). Individual plants were drip fertigated once or twice a day at $160 \mathrm{~mL} /$ pot, throughout.

Short photoperiod (SP) in the phytotron consisted of $10 \mathrm{~h}$ daylight [300 to $600 \mu \mathrm{mol} \cdot \mathrm{m}^{-2} \cdot \mathrm{s}^{-1} P P F$ (photosynthetic photon flux)]; long photoperiod (LP) consisted of $10 \mathrm{~h}$ daylight, plus 10 $\mathrm{h}$ incandescent light $\left[4 \mu \mathrm{mol} \cdot \mathrm{m}^{-2} \cdot \mathrm{s}^{-1} \mathrm{PAR}\right]$.

\section{Experimental setup}

EXPERIMENT 1. Mature intact bulbs from the July 2000 harvest were selected in October 2000, and subjected to dark storage at constant temperatures of $-2,2,4,9$, or $20^{\circ} \mathrm{C}$, RH $65 \%$ to $70 \%$, for 60 d. Medium-size cloves were planted on 5 Dec. 2000, at 17/9, $20 / 12$ or $23 / 15^{\circ} \mathrm{C}$ (day/night, respectively) under short and long photoperiods, or in a net-house under natural light (30\% shade), 18 plants per treatment (Table 1, Fig. 1).

Maximum leaf and scape lengths at bloom, and days to spathe break were recorded. Mean daily growth rate of floral scapes was determined as the ratio between final scape length and the number of days from the floral transition to the day of spathe break.

EXPERIMENT 2. Mature bulbs were harvested in July 2001. Mediumsize bulbs were sampled on 5 Sept. 2001, and stored in the dark for $60 \mathrm{~d}$ at $4{ }^{\circ} \mathrm{C}, \mathrm{RH} 65 \%$ to $70 \%$. Individual cloves, selected as above, were planted in the phytotron on 5 Nov., 15 to 40 plants per treatment. During their active growth, the plants were exposed to 13 thermoperiod and photoperiod treatments (Fig. 2).

Phenological data, including numbers of leaves, developmental stages of cloves, floral scape length, developmental stages of florogenesis, bulb weight, and bulb diameter, were monitored throughout growth and after harvest.

\section{Treatment}
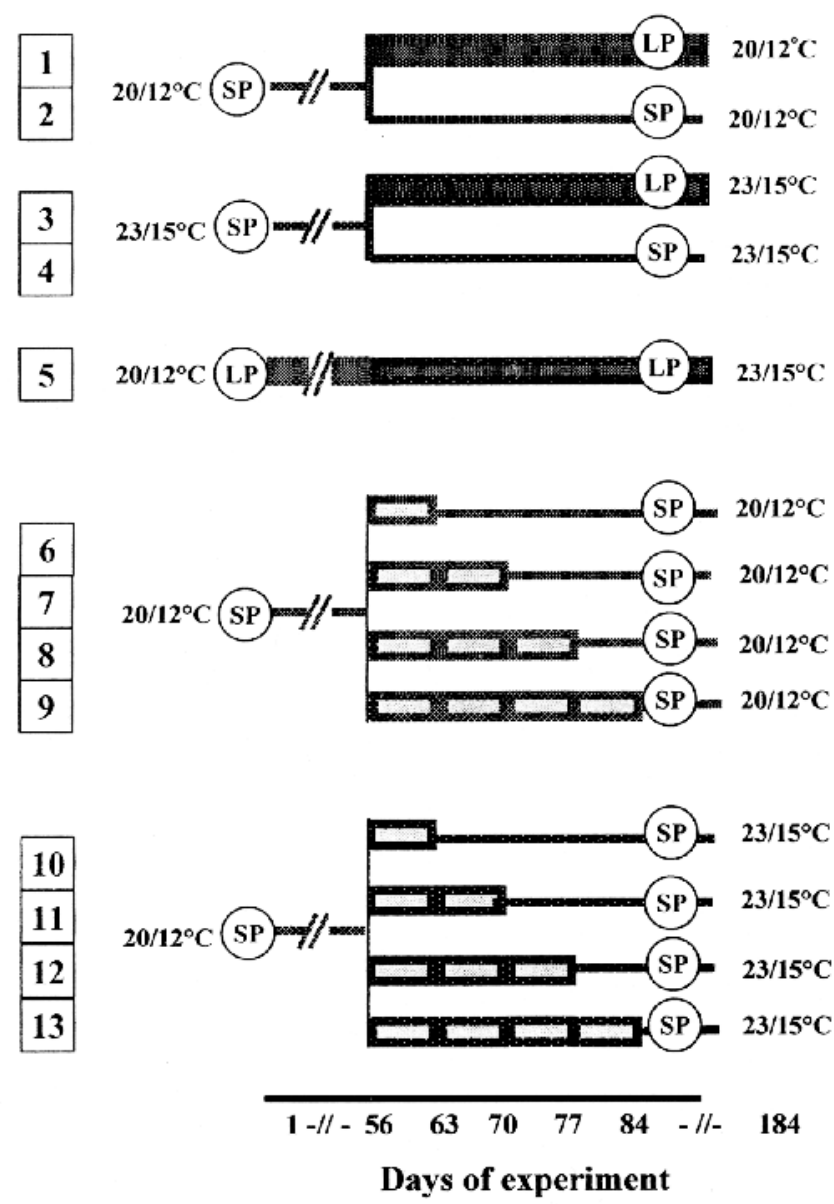

Fig. 2. Phytotron temperature and photoperiod treatments in 2001-02 experiments. Propagation bulbs were subjected to $60 \mathrm{~d}$ of constant storage temperature at $4{ }^{\circ} \mathrm{C}$ before planting. Short photoperiod $(\mathrm{SP})=10 \mathrm{~h}$ daylight; long photoperiod (LP) $=10 \mathrm{~h}$ daylight followed by $10 \mathrm{~h}$ of incandescent light. 
Destructive morphological analyses were performed weekly between the sixth and twelfth week of growth, and immediately after harvest, on three to five randomly selected plants per treatment. Developmental morphology was studied under a stereoscope (Zeiss Stemi 2000-C, Zeiss, Germany) and/or by scanning electron microscopy (SEM) (Kamenetsky, 1994). Before microscopic observations, freshly harvested plants were carefully stripped of their leaves, and the spathes were removed from the developing inflorescences. Samples for SEM were fixed in a mixture (by volume) of 5 glacial acetic acid : 5 formalin (40\%) : 90 ethanol $(70 \%)$ and were dehydrated in a graded acetone series $(35 \%, 70 \%$, $90 \%, 100 \%$ ) and freon. Immediately thereafter, tissues were dried using liquid $\mathrm{CO}_{2}$ in a Biorad 750 (England) critical-point dryer. Samples were then mounted on SEM stubs with double-sided tape, sputter-coated with $\approx 10 \mathrm{~nm}$ of gold and studied in a scanning electron microscope (JSM-35C; JEOL, Japan) with an accelerating potential of $15 \mathrm{kV}$.

STATISTICAL ANALYSIS. When required, two-way analysis of variance (ANOVA) was applied using the general linear model (GLM) procedure available on the SAS sofware package.

\section{Results}

Effects of storage and growth conditions on vegetative traits Leaf elongation. Plants from storage at $-2,2,4$, and $9{ }^{\circ} \mathrm{C}$ had longer foliage leaves than those from $20^{\circ} \mathrm{C}$ (Table 2). Lower growth temperatures had, in most cases, promoted leaf elongation. Plants grown in the net-house had significantly shorter leaves than those in the phytotron. Photoperiod in the second phase of the growth period had a marked effect on leaf size. In the phytotron, plants at LP had $\approx 15 \%$ to $25 \%$ longer leaves than those at SP (Table 2).

In a second experiment, storage at $4{ }^{\circ} \mathrm{C}$ for $60 \mathrm{~d}$ resulted in a typical leaf elongation of 70 to $100 \mathrm{~cm}$, under all phytotron conditions. Long photoperiod had no promoting effect, but under the same photoperiod, plants in warmer phytotron conditions (23/15 ${ }^{\circ} \mathrm{C}$ ) produced shorter leaves (data not shown).

DEVELOPMENT AND DORMANCY OF LATERAL BUDS. Morphological analysis revealed two whorls of lateral bud initials in the axils of the two youngest foliage leaves, under all environmental regimes in our study. Further clove development and dormancy induction, however, were affected by thermo- and photoperiod treatments throughout the entire phase of active plant growth.

Uninterrupted LP conditions throughout the experiment resulted in an early clove differentiation in the axils of the sixth and seventh leaves. Only six or seven lateral buds per plant were developed under these conditions, and temperature had no effect. Bud growth was rapid, and the cloves became dormant after 60 $\mathrm{d}$ of development. Consequently, bulbs from LP were ready to harvest at $112 \mathrm{~d}$ after planting, and fresh weight they accumulated

Table 2. Effect of storage and growth conditions on the length of the longest leaf (cm). Records were taken in April to May 2001. Details of growth conditions are presented in Table 1 . Means followed by the same letter are not different at $P=0.05$.

\begin{tabular}{|c|c|c|c|c|c|}
\hline \multirow{2}{*}{$\begin{array}{l}\text { Growth } \\
\text { conditions }\end{array}$} & \multicolumn{5}{|c|}{ Storage temp $\left({ }^{\circ} \mathrm{C}\right)$} \\
\hline & -2 & 2 & 4 & 9 & 20 \\
\hline $17 / 9^{\circ} \mathrm{C} \mathrm{SP}+17 / 9^{\circ} \mathrm{C} \mathrm{LP}$ & $84.2 \mathrm{a} \mathrm{A} \mathrm{A}^{z, y}$ & 88.6 a $\mathrm{A}$ & 88.6 a $\mathrm{A}$ & 83.5 a $\mathrm{A}$ & $56.1 \mathrm{~b} \mathrm{~B}$ \\
\hline $17 / 9^{\circ} \mathrm{C} \mathrm{SP}+20 / 12^{\circ} \mathrm{C} \mathrm{LP}+23 / 15^{\circ} \mathrm{C} \mathrm{LP}$ & 78.9 a $\mathrm{AB}$ & 80.3 a $\mathrm{AB}$ & 77.8 a BC & 81.5 a A & $65.8 \mathrm{~b} \mathrm{AB}$ \\
\hline $20 / 12{ }^{\circ} \mathrm{C} \mathrm{SP}+23 / 15^{\circ} \mathrm{C} \mathrm{LP}$ & $75.6 \mathrm{ab} \mathrm{BC}$ & 82.3 a A & $81.4 \mathrm{a} A B$ & 81.6 a $\mathrm{A}$ & $68.0 \mathrm{~b} \mathrm{~A}$ \\
\hline $17 / 9^{\circ} \mathrm{C} \mathrm{SP}+20 / 12^{\circ} \mathrm{C} \mathrm{SP}+23 / 15^{\circ} \mathrm{C} \mathrm{SP}$ & 72.5 a C & 74.4 a B & $69.2 \mathrm{ab} \mathrm{C}$ & $65.2 \mathrm{~b} \mathrm{~B}$ & $45.2 \mathrm{c} \mathrm{C}$ \\
\hline Net house & 58.9 a $\mathrm{D}$ & 56.7 a $\mathrm{C}$ & $55.3 \mathrm{a} \mathrm{D}$ & 49.4 a C & $28.7 \mathrm{~b} \mathrm{D}$ \\
\hline
\end{tabular}

${ }^{\mathrm{z}}$ Mean separation in rows by lower case letters indicates differences among storage temperatures, $P \leq 0.05, \mathrm{n}=18$.

y Mean separation in columns by upper case letters indicates differences among growth conditions, $P \leq 0.05, \mathrm{n}=18$.

Table 3 Effect of phytotron conditions on florogenesis and bulbing in garlic in 2001-02 (second experiment, details in Fig. 2). Following storage at 4 ${ }^{\circ} \mathrm{C}$ for $60 \mathrm{~d}$, medium-size cloves were planted in pots and placed in the phytotron on 5 Nov. 2001. Records were taken when $>50 \%$ of the population within a treatment reached the developmental stage in question. All time measurements refer to the planting date. Means \pm SE $(n=12)$.

\begin{tabular}{|c|c|c|c|c|c|c|c|c|c|}
\hline \multirow[b]{2}{*}{ Treatment } & \multicolumn{3}{|c|}{ Growth conditions } & \multirow[t]{2}{*}{$\begin{array}{c}\text { Mean } \\
\text { leaf no. } \\
\text { before scape } \\
\text { formation } \\
\quad( \pm \mathrm{SE})\end{array}$} & \multirow[t]{2}{*}{$\begin{array}{c}\text { Mean } \\
\text { final } \\
\text { scape } \\
\text { length } \\
\mathrm{cm}( \pm \mathrm{SE})\end{array}$} & \multirow[t]{2}{*}{$\begin{array}{l}\text { Plants } \\
\text { with } \\
\text { visible } \\
\text { scape } \\
(\%)\end{array}$} & \multirow{2}{*}{$\begin{array}{l}\text { Time to } \\
\text { spathe } \\
\text { break } \\
\text { (d) }\end{array}$} & \multirow{2}{*}{$\begin{array}{c}\text { Time to } \\
\text { bulb } \\
\text { harvest }^{z}(\mathrm{~d}) \\
\text { (d) }\end{array}$} & \multirow{2}{*}{$\begin{array}{c}\text { Mean } \\
\text { bulb wt } \\
(\mathrm{g})( \pm \mathrm{SE})\end{array}$} \\
\hline & Temp $\left({ }^{\circ} \mathrm{C}\right)$ & Days at SPy & Days at LP & & & & & & \\
\hline 1 & $20 / 12$ & 56 & 104 & $12.5 \pm 0.5$ & $80.8 \pm 4.0$ & 84.6 & 136 & 160 & $13.2 \pm 0.12$ \\
\hline 2 & $20 / 12$ & 184 & 0 & $11.0 \pm 0.5$ & $18.8 \pm 5.2^{x}$ & 0 & 0 & 184 & $24.8 \pm 3.54$ \\
\hline 3 & $20 / 12+23 / 15$ & 56 & 94 & $11.5 \pm 0.5$ & $54.2 \pm 3.0$ & 66.7 & 122 & 150 & $9.9 \pm 1.18$ \\
\hline 4 & $20 / 12+23 / 15$ & 156 & 0 & $13.0 \pm 0.6$ & $0.97 \pm 0.3^{x}$ & 0 & 0 & 156 & $13.3 \pm 0.85$ \\
\hline 5 & $20 / 12+23 / 15$ & 0 & 112 & $7.7 \pm 0.7$ & $57.4 \pm 4.1$ & 19.2 & 99 & 112 & $8.1 \pm 0.51$ \\
\hline 6 & $20 / 12$ & $56 / 121$ & 7 & $11.7 \pm 0.3$ & $49.2 \pm 2.4$ & 95.0 & 160 & 184 & $21.6 \pm 1.32$ \\
\hline 7 & $20 / 12$ & $56 / 114$ & 14 & $11.8 \pm 0.3$ & $58.8 \pm 2.3$ & 85.7 & 160 & 184 & $20.5 \pm 1.73$ \\
\hline 8 & $20 / 12$ & $56 / 107$ & 21 & $11.5 \pm 0.5$ & $56.9 \pm 1.9$ & 68.4 & 160 & 184 & $15.9 \pm 1.46$ \\
\hline 9 & $20 / 12$ & $56 / 100$ & 28 & $12.5 \pm 0.4$ & $64.8 \pm 2.9$ & 79.8 & 154 & 184 & $16.5 \pm 1.52$ \\
\hline 10 & $20 / 12+23 / 15$ & $56 / 93$ & 7 & $11.4 \pm 0.3$ & $50.5 \pm 5.5$ & 18.7 & Aborted & 156 & $11.5 \pm 0.76$ \\
\hline 11 & $20 / 12+23 / 15$ & $56 / 86$ & 14 & $12.7 \pm 0.3$ & $54.7 \pm 2.5$ & 66.7 & 134 & 156 & $12.5 \pm 0.65$ \\
\hline 12 & $20 / 12+23 / 15$ & $56 / 79$ & 21 & $12.3 \pm 0.5$ & $60.6 \pm 2.1$ & 56.2 & 134 & 156 & $11.6 \pm 0.93$ \\
\hline 13 & $20 / 12+23 / 15$ & $56 / 72$ & 28 & $12.0 \pm 0.9$ & $56.0 \pm 3.3$ & 80.0 & 134 & 156 & $11.2 \pm 0.8$ \\
\hline
\end{tabular}

${ }^{2}$ Bulbs were harvested ripened.

yBefore/after plant transition to LP.

XScape was buried inside the leaf sheathes. 


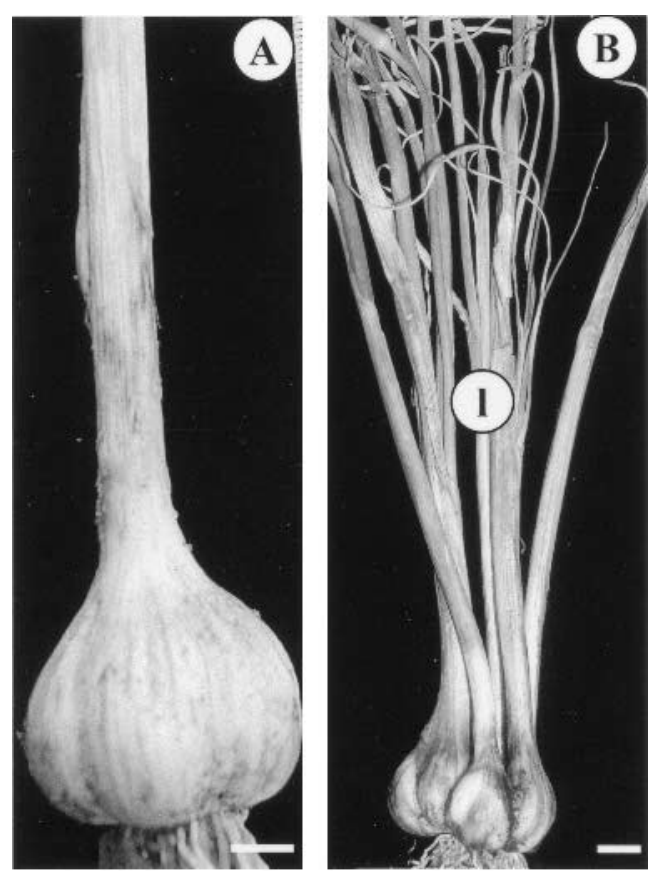

Fig. 3. Effect of growth conditions on bulbing and dormancy induction. (A) Dormant bulb, formed after $112 \mathrm{~d}$ of growth at continuous LP, at 25 Feb. 2002. Bar $=1 \mathrm{~cm}$. (B) Under uninterrupted SP, the differentiated lateral buds develop into slender leaves (1) and do not enter dormancy after $184 \mathrm{~d}$ of growth, 9 May 2002. Bar $=1 \mathrm{~cm}$

was the lowest compared with plants from other environmental treatments (Table 3).

UnderSPconditions, initiation of 8 to 10 lateral buds was observed at the axils of the 10th and 11th leaves. Following initiation, a transfer from SP to LP enhanced growth of lateral buds, and bulb ripening was evident 150 to $160 \mathrm{~d}$ after planting (Table 3, Fig. 3a).

Under an uninterrupted SP regime, the differentiated axillary buds sprouted and developed into long and slender leaves, between the youngest green foliage leaves. In general, plants did not enter dormancy, except for those in the warm regime of $23 / 15^{\circ} \mathrm{C}$ where $\approx 20 \%$ of the bulbs became dormant. The other plants under warm and cooler conditions maintained their axillary leaves green till the end of the experiment (Fig. 3b). Bulbing was slow, and large bulbs with nondormant cloves were harvested from the 23/15 and
$20 / 12^{\circ} \mathrm{C}$ regimes after 156 and $184 \mathrm{~d}$ from planting, respectively, under SP (Table 3). A similar phenomenon was recorded for $\approx 60 \%$ of the plants at $20 / 12^{\circ} \mathrm{C}$ when the short photoperiod regime was interrupted by 1 week of LP.

Interruption of the short photoperiod regime by 14 to $28 \mathrm{~d}$ of LP was sufficient for dormancy induction of the lateral buds, regardless of the temperature regime. The date of bulb maturation, however, was temperature dependent. Thus, at $20 / 12^{\circ} \mathrm{C}$ maturation occurred one month later than at higher temperatures. Consequently, harvest was delayed and bulbs grown at lower temperatures were usually heavier under all photoperiods than those grown at higher temperatures (Table 3).

\section{Effects of storage and growth conditions on reproductive traits}

Transition from vegetative to REPRODUCtive STATE. The transition of the apical meristem from the vegetative to the reproductive state occurred in all growing plants (Tables 3 and 4). The physiological age at which the plants underwent this major change was significantly affected by their storage treatment and growth conditions. In the first experiment, storage at temperatures $<20^{\circ} \mathrm{C}$ resulted in a floral transition after the differentiation of six to eight leaves, while storage at $20^{\circ} \mathrm{C}$ resulted in a floral transition after the differentiation 11 to 14 leaves (Table 4, Fig. 4a and b).

In the second experiment, following preplanting storage at $4^{\circ} \mathrm{C}$, the earliest meristem transition from the vegetative to the reproductive state occurred after formation of seven or eight leaves under long photoperiod. This change was already visible $40 \mathrm{~d}$ after planting. Under SP and $20 / 12^{\circ} \mathrm{C}$, the transition was first observed in plants with 11 to 13 leaves at 50 to $55 \mathrm{~d}$ (Table 3).

SCAPE ELONGATION. In the first experiment, significant effects of storage and growth conditions were evident on both daily growth rate of the floral scape and the date of the spathe break (Table 4, Fig. 5). Storage at either -2 or $20^{\circ} \mathrm{C}$ resulted in the lowest rate of scape elongation, and the latest spathe break, whereas fastest growth rates were recorded in plants from cold storage and the cooler phytotron environment (Fig. 5).

The combined effect of storage at $20^{\circ} \mathrm{C}$ and warmer phytotron temperatures or ambient spring temperatures in the net house, was insufficient for induction of scape elongation. The process was also arrested under SP in plants pretreated in storage at $-2,9$, or $20^{\circ} \mathrm{C}$, while plants under SP from storage at 2 or $4{ }^{\circ} \mathrm{C}$, developed only short scapes 18 to $20 \mathrm{~cm}$ long. Under net-house conditions, bolting

Table 4. Effect of storage and growth conditions on leaf number before floral transition and on date of spathe break in garlic in $2000-01$ (first experiment, details in Table 1). Leaf number was recorded in dissected plants in February to March 2001. Records for spathe break were taken in April to July 2001, when $>50 \%$ of the population within a treatment reached the developmental stage in question. The time measurements refer to the planting date. Means $\pm \operatorname{SE}(\mathrm{n}=5)$.

\begin{tabular}{|c|c|c|c|c|c|c|c|c|c|c|}
\hline \multirow[b]{3}{*}{ Growth conditions } & \multicolumn{10}{|c|}{ Storage temp $\left({ }^{\circ} \mathrm{C}\right)$} \\
\hline & \multicolumn{2}{|c|}{-2} & \multicolumn{2}{|c|}{2} & \multicolumn{2}{|c|}{4} & \multicolumn{2}{|c|}{9} & \multicolumn{2}{|c|}{20} \\
\hline & $\begin{array}{c}\text { Mean } \\
\text { leaf no. } \\
\text { before } \\
\text { floral } \\
\text { transition } \\
( \pm \text { SE })\end{array}$ & $\begin{array}{l}\text { Time to } \\
\text { spathe } \\
\text { break } \\
\text { (d) }\end{array}$ & $\begin{array}{l}\text { Mean } \\
\text { leaf no. } \\
\text { before } \\
\text { floral } \\
\text { transition } \\
( \pm S E)\end{array}$ & $\begin{array}{l}\text { Time to } \\
\text { spathe } \\
\text { break } \\
\text { (d) }\end{array}$ & $\begin{array}{c}\text { Mean } \\
\text { leaf no. } \\
\text { before } \\
\text { floral } \\
\text { transition } \\
( \pm \mathrm{SE})\end{array}$ & $\begin{array}{l}\text { Time to } \\
\text { spathe } \\
\text { break } \\
\text { (d) }\end{array}$ & $\begin{array}{l}\text { Mean } \\
\text { leaf no. } \\
\text { before } \\
\text { floral } \\
\text { transition } \\
( \pm \text { SE })\end{array}$ & $\begin{array}{c}\text { Time to } \\
\text { spathe } \\
\text { break } \\
\text { (d) }\end{array}$ & $\begin{array}{c}\text { Mean } \\
\text { leaf no. } \\
\text { before } \\
\text { floral } \\
\text { transition } \\
( \pm \text { SE })\end{array}$ & $\begin{array}{c}\text { Time to } \\
\text { spathe } \\
\text { break } \\
\text { (d) }\end{array}$ \\
\hline $17 / 9^{\circ} \mathrm{C} \mathrm{SP}+17 / 9^{\circ} \mathrm{C} \mathrm{LP}$ & $7.7 \pm 0.7$ & 100 & $7.8 \pm 0.3$ & 95 & $7.0 \pm 0.4$ & 95 & $7.7 \pm 0.3$ & 98 & $11.8 \pm 0.3$ & 148 \\
\hline $17 / 9^{\circ} \mathrm{C} \mathrm{SP}+20 / 12^{\circ} \mathrm{C} \mathrm{LP}+23 / 15^{\circ} \mathrm{C} \mathrm{LP}$ & $7.8 \pm 0.3$ & 96 & $7.7 \pm 0.7$ & 100 & $7.2 \pm 0.6$ & 95 & $8.7 \pm 0.6$ & 95 & $12.7 \pm 0.7$ & 130 \\
\hline $20 / 12^{\circ} \mathrm{C} \mathrm{SP}+23 / 15^{\circ} \mathrm{C} \mathrm{LP}$ & $7.1 \pm 0.2$ & 93 & $6.8 \pm 0.5$ & 96 & $6.9 \pm 0.5$ & 95 & $7.1 \pm 0.3$ & 92 & $11.5 \pm 0.5$ & 130 \\
\hline $17 / 9^{\circ} \mathrm{C} \mathrm{SP}+20 / 12^{\circ} \mathrm{C} \mathrm{SP}+23 / 15^{\circ} \mathrm{C} \mathrm{SP}$ & $8.1 \pm 0.3$ & $148^{z}$ & $8.1 \pm 0.2$ & 148 & $9.3 \pm 0.2$ & 161 & $9.7 \pm 0.8$ & $148^{z}$ & $14.2 \pm 0.3$ & $---y$ \\
\hline Net house & $6.3 \pm 0.2$ & 118 & $7.7 \pm 0.7$ & 120 & $7.7 \pm 0.5$ & 119 & $7.1 \pm 0.1$ & 148 & $7.6 \pm 0.5$ & 148 \\
\hline
\end{tabular}

Flowers aborted after spathe break.

yFlower scape was buried inside the leaf sheathes. 


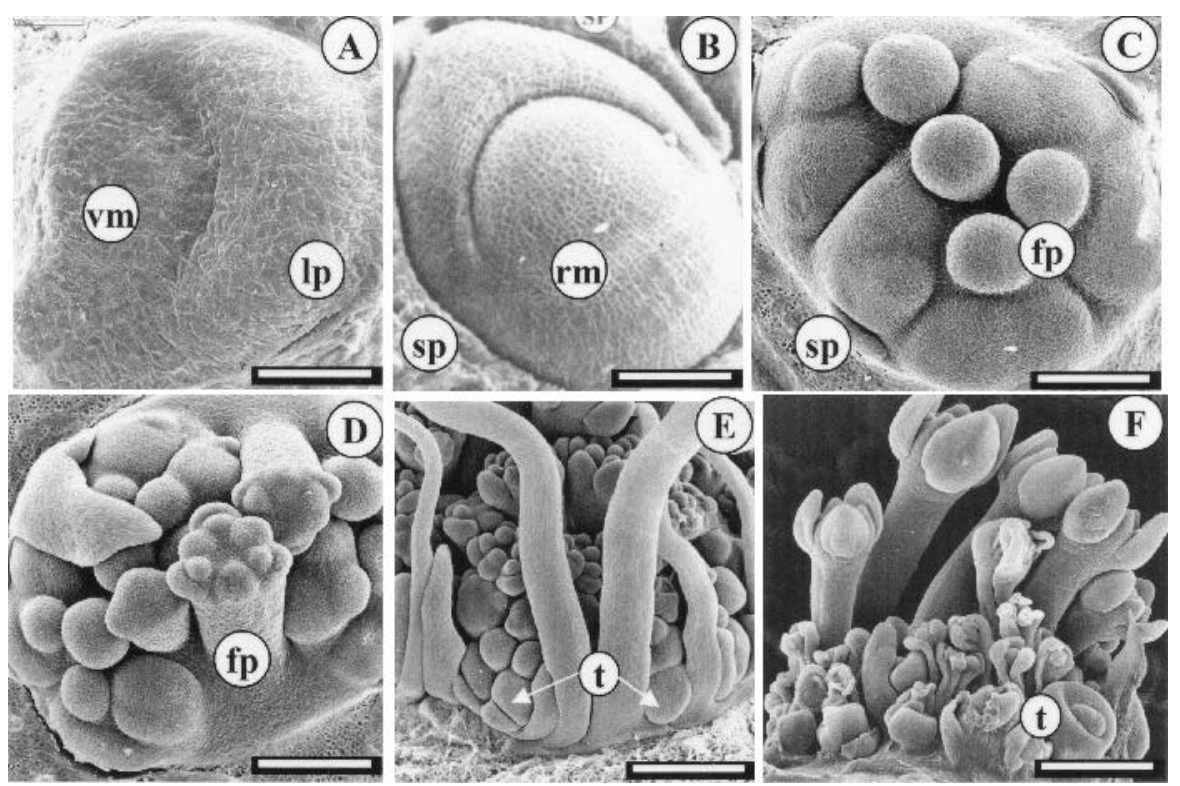

of inflorescence development, the apical meristem subdivides to form several swellings, each of which gives rise to a number of individual floral primordia (Fig. 4c). This is followed by increases in both the size of the developing inflorescence and the number of floral primordia. The differentiation of individual flowers begins when the developing inflorescence reaches a diameter of $\approx 2$ to $3 \mathrm{~mm}$. This process occurs in the oldest floral buds, while younger ones still emerge as undifferentiated meristematic domes (Fig. 4d).

Following flower differentiation, new undifferentiated domes become visible at the periphery of the inflorescence, and these quickly differentiate and grow to form topsets (Fig. 4e). Under our experimental conditions, the photoperiod I regime prevailing during scape elongation significantly affected the development of these vegetative buds in the inflorescence.

Fig. 4. Scanning electron photomicrographs of garlic apical and floral development. (A) Vegetative meristem (vm) with differentiated leaf primordium (lp). Bar = $0.1 \mathrm{~mm}$. (B) Floral transition. The reproductive meristem ( $\mathrm{rm})$ is swollen and hemispherical. The spathe (sp) was removed. Bar $=0.1 \mathrm{~mm}$. (C) Differentiation of flower primordia in a reproductive meristem, with spathe removed. First flower primordia (fp) are initiated in a $0.8-\mathrm{mm}$-diameter apex. Bar $=0.3 \mathrm{~mm}$. (D) Differentiation of floral primordia in garlic inflorescence. Floral parts occur in the oldest floral primordia (fp), while younger ones still appear as undifferentiated meristematic domes. Bar $=0.4 \mathrm{~mm}$. (E) Newly developed meristems appear near leaf-like bracts at the base of the inflorescence. They quickly differentiate and grow to form small inflorescence bulbs: topsets (t). Bar $=0.8 \mathrm{~mm}$. (F) Growth at $23 / 15^{\circ} \mathrm{C}$ and SP with 1 week interruption by LP results in the inflorescence aborting and drying at the early stages of its development. Bar $=1 \mathrm{~mm}$.

plants always reached spathe break later than the corresponding plants in the phytotron. Long photoperiod and warmer phytotron conditions resulted in shorter scapes and earlier spathe break than occurred in the corresponding plants in the cooler environment.

In the second experiment, morphodevelopmental studies reconfirmed the strong environmental effect on scape elongation. Following floral initiation and transfer from SP to LP, final scape length was markedly affected by temperature, and reached 80 and $55 \mathrm{~cm}$ under cooler and warmer phytotron conditions, respectively (Table 3).

Under continuous LP, scape elongation began immediately after the initiation of the floral meristem, and continued rapidly, in tandem with flower differentiation. However, scape elongation was evident only in $<20 \%$ of the experimental population. In the responsive plants, scapes were short, and spathe break occurred at $99 \mathrm{~d}$ after planting (Table 3, treatment 5). Under continuous SP, scape elongation was slow, and high temperature further inhibited its development (Table 3, treatments 2 and 4).

When the SP regime was interrupted with 1 week of LP, scape elongation was slightly inhibited, and at higher temperatures the inflorescence was aborted (Table 3, treatments 6 and 10). Two to 4 weeks of interruption of SP with LP result in normal scape elongation both at low and high temperatures. High temperatures reduced the percentage of bolting plants under all photoperiod conditions (Table 3 ).

INFLORESCENCE DIFFERENTIATION AND COMPLETION OF FLORAL DEVELOPMENT. In the initial stages
When SP was followed by LP, and under uninterrupted LP conditions, both flowers and topsets developed in the inflorescence, and the final inflorescence diameter reached $4 \mathrm{~cm}$. The fully differentiated flower buds were physically squeezed by the rapidly growing topsets, and degenerated and dried out before anthesis (Figs. 4a and b).

Under continuous SP, abortion of the differentiated inflorescence occurred early in the development, when the arrested scapes were still enveloped by the leaf sheaths inside the false stem.

At $20 / 12^{\circ} \mathrm{C}$ and SP, an interruption by 1 week of LP resulted in normal flower differentiation with the formation of only a few vegetative buds in the umbel, and full anthesis occurred after spathe break (Fig. 6c and d). At $23 / 15^{\circ} \mathrm{C}$, a 1-week interruption of SP by LP resulted in a large-scale abortion of young floral buds during the early stages of differentiation; the inflorescence dried out long before spathe break and anthesis (Fig. 4f).

At either low or high temperatures, the effect of LP interruption on plants at SP was directly related to the length of the treatment. The longer the LP period, the larger was the diameter of the inflorescences, thus reaching $1.5,2.7$, or $2.9 \mathrm{~cm}$, at 2,3 , or 4 weeks of LP exposure, respectively. The number of topsets increased progressively with duration of the LP, concurrently with inflorescence size, with the consequent squeezing and strangulating of the floral buds.

Fig. 5. Effect of storage temperature and growth conditions (details in Table 1) on mean daily growth rate of the floral scapes. September 2000 to May 2001.
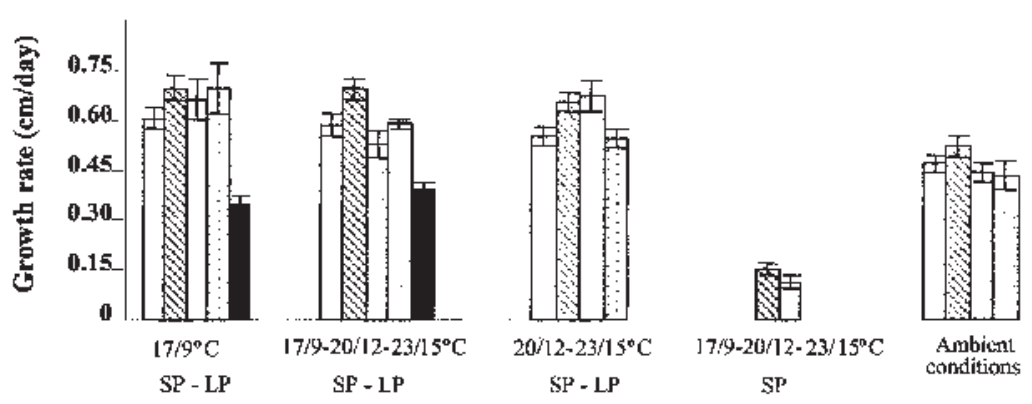

Growth conditions
口 $-2 \% \mathrm{C}$

(5 $2^{\circ} \mathrm{C}$

$\square 4^{\circ} \mathrm{C}$

(9) $9^{\circ} \mathrm{C}$

- $20^{\circ} \mathrm{C}$ 

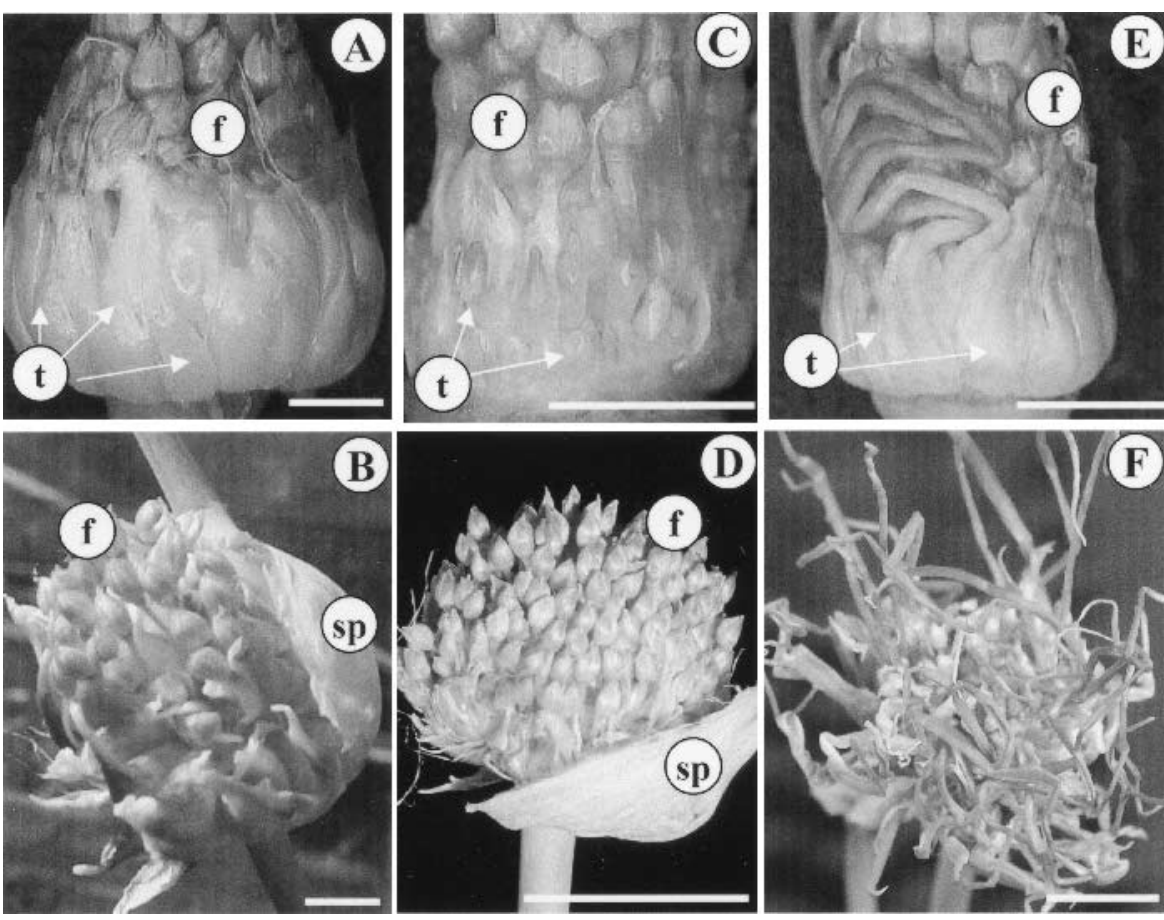

Fig. 6. Inflorescence development in garlic as affected by growth conditions. Intact bulbswere stored at $4{ }^{\circ} \mathrm{C}$ for 60 $\mathrm{d}$ before planting in the phytotron on 5 Nov. 2001. (A) Microphotograph of the developing inflorescence with both flowers (f) and topsets (t). Plants were initially grown for 8 weeks under the SP regime and $20 / 12{ }^{\circ} \mathrm{C}$, and then transferred to LP until the end of the experiment. $27 \mathrm{Feb}$. 2002. Bar $=0.2 \mathrm{~cm}$. (B) Inflorescence formed by flowers (f) and dormant topsets (t), after spathe break. Flowers are physically squeezed by topsets, and are dried out before anthesis. Plants were initially grown for 8 weeks under the SP regime and $20 / 12^{\circ} \mathrm{C}$, and then transferred to $\mathrm{LP}$ until the end of the experiment. 7 Apr. 2002. Bar $=1 \mathrm{~cm}$. (C) Microphotograph of the developing inflorescence with flowers (f) and topsets (t). Plants were grown at $20 / 12^{\circ} \mathrm{C}$ and SP regime for 8 weeks, then transferred to LP for 1 week, and returned to SP for further growth. Note undeveloped topset initials in the periphery of the inflorescence. 26 Feb. 2002. Bar $=0.2 \mathrm{~cm}$. (D) Inflorescence formed by flowers (f) after spathe break before anthesis. Plants were grown at $20 / 12^{\circ} \mathrm{C}$ and SP regime for 8 weeks, then transferred to LP for 1 week, and returned to SP for further growth. 13 May 2002. Bar = 1 $\mathrm{cm}$. (E) Microphotograph of the developing inflorescence with flowers (f) and topsets (t). Plants were grown at $20 / 12^{\circ} \mathrm{C}$ and SP regime for 8 weeks, then transferred to LP for 3 weeks, and returned to SP for further growth. Note nondormant topset initials, producing green leaves. 26 Feb. 2002. Bar $=0.2 \mathrm{~cm}$. (F) Inflorescence formed by flowers and green leaves after spathe break. Flowers

In plants exposed to only 2 or 3 weeks of LP, the vegetative meristems mostly formed slender leaves instead of topsets (Fig. 6e and f), whereas 4 weeks of LP interruption resulted in a mixed population of dormant and nondormant topsets.

\section{Discussion}

For many years, research on garlic focused on vegetative development (e.g., Brewster, 1994; Burba, 1993; Messiaen et al., 1993; Takagi, 1990). The recent discovery of fertile plants (Etoh, 1986; Etoh and Simon, 2002; Kamenetsky et al., 2003, 2004; Kotlinska et al., 1991) and the results of the consequent research on garlic florogenesis (Etoh and Simon, 2002; Kamenetsky and Rabinow- are physically squeezed by developing vegetative buds (nondormant topsets) and dried out before anthesis. Plants were grown at $20 / 12{ }^{\circ} \mathrm{C}$ and SP regime for 8 weeks, then transferred to LP for 3 weeks, and returned to SP for further growth. 17 May 2002. $\mathrm{Bar}=1 \mathrm{~cm}$. Abbreviations: $\mathrm{vm}=$ vegetative meristem, $\mathrm{rm}$ $=$ reproductive meristem, $\mathrm{sp}=$ spathe, $\mathrm{fp}=$ floral primordium, $\mathrm{f}=$ differentiated flower, $\mathrm{t}=$ topset.

itch, 2001; Takagi, 1990) facilitated the study of the environmental regulation of the interactive relationships between the developing vegetative and reproductive organs.

As in many geophytes (Le Nard and De Hertogh, 1993), we identified four distinct phases in garlic florogenesis: 1) transition, 2) scape elongation, 3) inflorescence differentiation, and 4) completion of floral development to anthesis.

In all growing plants of accession \#2091, foliage leaf and lateral bud formation were followed by a complete transition of the apical meristem from the veg-
Non-dormant topsets; sprouting of slender leaves;

\section{Completion of floral}

development; anthesis
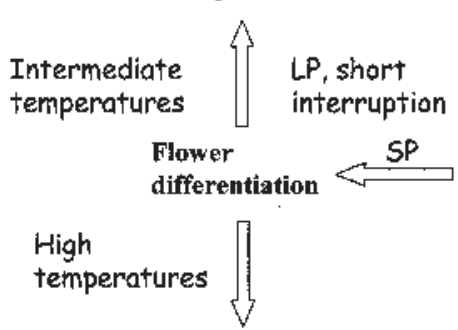

Flower abortion at early stages

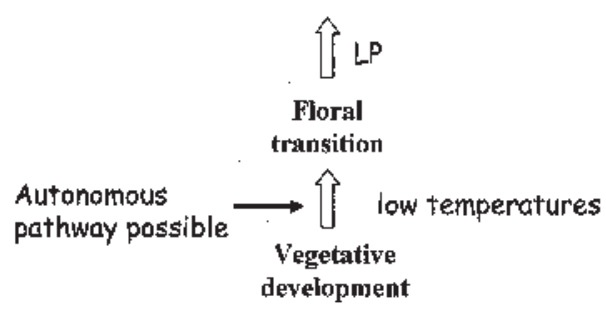
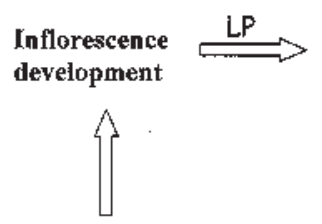

Srape elongation

Fioral

ransition flower obliteration

$$
\left\{\begin{array}{l}
\text { LF, short } \\
\text { interruption }
\end{array}\right.
$$

Differentiation of vegetative buds

$$
\left\{\begin{array}{l}
\text { LP, long } \\
\text { exposure }
\end{array}\right.
$$

Dormant topsets; flower degeneration etative to the reproductive state under a variety of storage and growth conditions. We conclude that as in other geophytes (e.g., Hippeastrum: Hartsema, 1961; Okubo, 1993; A. aflatunense: Zemah, 2001) and in Arabidopsis (Michaels and Amasino, 2000; Reeves and Coupland, 2000), meristem transition in garlic accession \#2091 is autonomous, and that the environment has only a quantitative effect. In Arabidopsis, it was proposed that autonomous transition serves as an alternative to the major route of floral initiation, which is regulated by low temperatures or LP (Reeves and Coupland, 2000).

In garlic, as in many other Allium species (Kamenetsky and Rabinowitch, 2002; Yamasaki et al., 2000), low temperatures promoted floral transition. However, unlike the qualitative (absolute) requirement described for a number of Japanese varieties (Takagi, 1990), low temperatures had only a quantitative effect

Fig. 7. Scheme of florogenesis of garlic, as affected by environmental conditions. 
in garlic accession \#2091, and storage at $20^{\circ} \mathrm{C}$ resulted in shorter leaves, delayed floral transition, and slower scape elongation than in plants from cold storage. In addition to the thermoperiod effects, the numbers of leaves and leaf primordia before floral transition were significantly smaller in plants initially exposed to LP than in those initially exposed to SP.

In Allium species the completion of scape elongation is essential for a successful bloom. The process strongly depends on storage and growth temperatures, and photoperiod is markedly involved (Kamenetsky and Rabinowitch, 2002). For instance, growth temperatures of 17 to $20{ }^{\circ} \mathrm{C}$ combined with long photoperiod enhanced scape elongation in onion, shallot, and other Allium species, while higher temperatures of 25 to $30{ }^{\circ} \mathrm{C}$ suppressed the emergence of inflorescences that were already initiated (De Hertogh and Zimmer, 1993; Krontal et al., 2000; Maeda et al., 1994; Rabinowitch, 1990). In garlic, cold storage promotes scape elongation, the optimum for \#2091 ranged between 2 and $4{ }^{\circ} \mathrm{C}$ and LP promoted bulb formation, dormancy, and scape elongation.

In \#2091, normal scape elongation was obtained only following an exposure to a sequential photoperiod treatment of SP, following by LP conditions. Similarly, in Japanese bunching onion, early LP treatment may inhibit flowering, but at a later stage, when the inflorescence reaches a certain stage of development, LP promotes scape elongation (Yamasaki et al., 2000).

In our experiments, LP is both obligatory and quantitative for the vegetative and reproductive processes. Under continuous SP, scapes remained inside the false stem, and LP interruption was required for elongation beyond the leaf sheaths. Under exclusively LP conditions, scape elongation was fast, but, nevertheless, only a few plants reached maximum inflorescence size and spathe-break, probably because of internal competition for assimilates between the developing bulb and inflorescence (Rosen and Tong, 2001; van Kampen, 1970).

As in bulb onion, bulb development in garlic is followed by dormancy induction. Both processes are regulated by endogenous hormonal balance (Isenberg et al., 1974) as well as by internal competition for assimilates between the reproductive and the vegetative (storage) organs (bulb onion: Abdalla and Mann, 1963; Brewster, 1990, 1994; van Kampen, 1970; garlic: Rosen and Tong, 2001; Takagi 1990). Increasing day length and temperature cause in bulb onion withering and death of the young scape (Roberts and Struckmeyer, 1951; van Kampen, 1970), or the partially formed inflorescence reverts to a vegetative type of growth, and sometimes produces topsets (Roberts and Struckmeyer, 1951).

In agreement with previous findings (Messiaen et al., 1993; Takagi, 1990), our experiments showed that the induction of dormancy in lateral cloves required $>2$ weeks exposure to LP, whereas a regime of cold conditions and SP resulted in sprouting and growth of the axillary buds, and lack of dormancy. An optimal inflorescence development, with viable flowers and without topsets was observed in garlic plants exposed to SP, with only one week interruption of LP. This short exposure to LP triggers scape elongation in post-transitional plants and permits the further development of the inflorescence and the completion of florogenesis with minimum competition by the development of storage organs. Indeed, a longer period of LP interruption promotes diversion from the generative pathway towards a vegetative route, bulb formation, and dormancy initiation.

In garlic, the preference for topsets over flower production in the inflorescence is not clear. In a recent review, Etoh and Simon (2002) stated that the primitive forms of garlic originally produced umbels with mixed populations of flowers and topsets. Roberts and Struckmeyer (1951) suggested that in bulb onion, topset development is promoted by environmental conditions that are conducive to bulbing. In the studied garlic inflorescence, differentiation of topsets follows flower formation and is dominated by photoperiod. Under SP conditions (including 1 week interruption by LP for scape elongation), the developing inflorescence of \#2091 contained flowers only, each of which reached full anthesis. A 2to 3-week interruption by LP, however, was adequate to induce vegetative differentiation in the umbel and yet too short to induce dormancy of the developing topsets. Nevertheless, this treatment was sufficient to induce dormancy in the cloves, thus indicating a differential hormonal balance or requirements in the basal and apical vegetative sets.

Ten millennia of selection for an increased proportion of resources in the bulbs, and for earliness, resulted in suppression of florogenesis in garlic (Etoh and Simon, 2002). We further speculate that this selection pressure led to both earliness and dormancy induction, enhanced translocation towards the growing cloves, and a specific endogenous hormonal balance that favors the production of storage organs. Under marginal conditions for bulbing, the two processes - floral development and bulbing - occur simultaneously, but the differentiating apical meristem is affected by the hormonal makeup, which favors storage organs and therefore forms topsets. The similarity of photoperiod effects on the formation and dormancy of cloves and of topsets (Fig. 7) further supports this hypothesis. However, basic hormonal studies are required.

We conclude that in bolting garlic, sophisticated manipulation of the environment, both before and after planting, can lead to the development of viable flowers in a topset-free umbel. However, normal flowering cannot be achieved if any of the four developmental stages of florogenesis is retarded or proceeds in the wrong direction (Fig. 7).

We have shown that environmental conditions, especially temperature and photoperiod, strongly affect garlic morphology and development, including leaf elongation, clove formation, and dormancy induction, and that the environmental regulatory effect is obligatory and yet quantitative. This is true also for each of the post-transitional stages of florogenesis. In addition to their immediate effects, environmental factors also have long-term effects on each of the stages of floral development (Fig. 7). With the exception of the apex floral transition (which may occur autonomously), environmental conditions during both storage and growth affect the progress and direction of further development into either the reproductive or the vegetative pathway, as is common in many other geophytes (Le Nard and De Hertogh, 1993).

Normal flowering in garlic is achieved in plants exposed to a specific sequence of environmental effects, thus indicating that the genome of \#2091 contains all the genes necessary for flowering, and that the process is controlled by a cascade of genetic factors coding for the different phases and differentially regulated by day length and temperature. Hence, an intimate knowledge of the complicated interactions between the genes and the environment should facilitate fertility restoration in garlic genotypes, which contain the complete set of genetic factors for flowering and seed production (Kamenetsky et al., 2003, 2004).

\section{Literature Cited}

Abdalla, A.A. and L.K. Mann. 1963. Bulb development in the onion (Allium cepa L.) and the effect of storage temperature on bulb rest. Hilgardia 35:85-112.

Brewster, J.L. 1990. Physiology of crop growth and bulbing, p. 53-88. In: H.D. Rabinowitch and J.L. Brewster (eds.). Onions and allied crops. 
vol. 1. CRC Press, Boca Raton, Fla.

Brewster, J.L. 1994. Onions and other vegetable alliums. CAB Intl., Wallingford, U.K.

Burba, J.L. 1993. Producción de "Semilla" de Ajo. Asociación Cooperadora EEA, La Consulta, Argentina.

De Hertogh, A.A. and K. Zimmer. 1993. Allium-Ornamental species, p. 187-200. In: A.A. De Hertogh and M. Le Nard (eds.). The physiology of flower bulbs. Elsevier, Amsterdam.

Etoh, T. 1985. Studies on the sterility in garlic Allium sativum L. Mem. Fac. Agr. Kagoshima Univ. 21:7-132.

Etoh, T. 1986. Fertility of the garlic clones collected in Soviet central Asia. J. Jpn. Soc. Hort. Sci. 55:312-319.

Etoh, T. and P.W. Simon. 2002. Diversity, fertility and seed production of garlic, p. 101-117. In: H.D. Rabinowitch and L. Currah (eds.). Allium crop science: recent advances. CAB Intl., Wallingford, U.K.

Etoh, T., Y. Noma, Y. Nishitarumizu, and T. Wakomoto. 1988. Seed productivity and germinability of various garlic clones collected in Soviet central Asia. Mem. Fac. Agr. Kagoshima Univ. 24:29-139.

Hartsema,A.M. 1961. Influence of temperatures on flower formation and flowering of bulbous and tuberous plants, p. 123-167. In: W. Ruhland (ed.). Handbuch der Pflanzenphysiologie. vol. 16. Springer-Verlag, Berlin, Germany.

Isenberg, F.M.R., T.H. Thomas, M. Pendergrass, and M. Abdel-Rahman. 1974. Hormone and histological differences between normal and maleic hydrazide treated onions stored over winter. Acta Hort. 38:95-126.

InabaA., T. Ujiie, and T. Etoh. 1995. Seed productivity and germinability of garlic (in Japanese). Breeding Sci. 45(suppl.)2:310.

Jenderek, M.M. 1998. Generative reproduction of garlic (Allium sativum) (in Polish). Sesja Naukowa 57:141-145.

Kamenetsky, R. 1994. Life cycle, flower initiation and propagation of the desert geophyte Allium rothii. Intl. J. Plant Sci. 155:597-605.

Kamenetsky, R. and H.D. Rabinowitch. 2001. Floral development in bolting garlic. Sexual Plant Reprod. 4:235-241.

Kamenetsky, R. and H.D. Rabinowitch. 2002. Florogenesis, p. 31-58. In: H.D. Rabinowitch and L. Currah (eds.). Allium crop science: Recent advances. CAB Intl., Wallingford, U.K.

Kamenetsky, R., I. London, F. Khassanov, C. Kik, and H.D. Rabinowitch. 2003. Garlic (Allium sativum L.) and its wild relatives from central Asia: Evaluation for fertility potential. Acta Hort. (in press).

Kamenetsky, R., I.London Shafir,F. Khassanov, C. Kik,A.W van Heusden, M. Vrielink-van Ginkel, K. Burger-Meijer, J. Auger, I. Arnault, and H.D. Rabinowitch. 2004. Diversity in fertility potential and organosulphur compounds among garlics from central Asia. Biodiversity and Conservation (in press).

Keller E.R.J. 2002. Cryopreservation of Allium sativum L. (Garlic), p. 37-47. In: L.E. Towill and Y.P.S. Bajaj (eds.). Cryopreservation of plant germplasm. vol. 2. Springer-Verlag, Berlin Heidelberg, Germany.

Kondo, T., H. Hasegawa, and M.Suzuki. 2000. Transformation and regeneration of garlic (Allium sativum L.) by Agrobacterium-mediated gene transfer. Plant Cell Rpt. 19: 989-993.

Kononkov P.F. 1953. The question of obtaining garlic seed (in Russian). Sad i Ogorod 8:38-40.

Konvicka O. 1984. Generative Reproduktion von Knoblauch (Allium sativum) (in German). Allium Nwsltt. 1: 28-37.

Kotlinska, T., P. Havranek, M. Navratill, L. Gerasimova, A. Pimakhov, and S. Neikov. 1991. Collecting onion, garlic and wild species of $\mathrm{Al}$ - lium in central Asia, USSR. FAO/IBPGR Plant Genet. Resour. Nwsltt. 83/84:31-32.

Koul, A.K. and R.N. Gohil. 1970. Causes averting sexual reproduction in Allium sativum. Linn. Cytologia 35:197-202.

Krontal, Y., R, Kamenetsky, H.D. Rabinowitch. 2000. Flowering physiology and some vegetative traits of short-day shallot-A comparison with bulb onion. J. Hort. Sci. Biotechnol. 75:35-41.

Le Nard, M. and A.A. De Hertogh. 1993. Bulb growth and development and flowering, p. 29-44. In: A.A. De Hertogh and M. Le Nard (eds.). The physiology of flower bulbs. Elsevier, Amsterdam, the Netherlands.

Maeda, M., J.G. Dubouzet, K.I. Arisumi, T, Etoh, and Y. Sakata. 1994. Effects of cold storage and staggered planting in forcing culture of spring-flowering Allium species. J. Jpn. Soc. Hort. Sci. 63:629-638.

Messiaen, C.M., J. Cohat, J.P. Leroux, M. Pichon, and A. Beyries. 1993. Les alliums alimentaires reproduits par voie végétative. INRA, Paris, France.

Michaels, S.D. and R.M Amasino. 2000. Memories of winter: Vernalization and the competence to flower. Plant Cell Environ. 23: $1145-1153$

Novak, F.J. 1990. Allium tissue culture, p. 233-250. In: H.D. Rabinowitch and J.L. Brewster (eds.). Onions and allied crops. vol. 1. CRC Press, Boca Raton, Fla.

Novak F.J. and P. Havranek. 1975. Attempts to overcome the sterility of common garlic (Allium sativum). Biologia Plantarum (Praha) 17: 376-379.

Okubo, H. 1993. Hippeastrum (Amaryllis), p. 321-334. In: A.A. De Hertogh and M. Le Nard (eds.). The physiology of flower bulbs. Elsevier, Amsterdam, the Netherlands.

Pooler, M.R. and P.W. Simon. 1993. Garlic flowering in response to clone, photoperiod, growth temperature, and cold storage. HortScience 28:1085-1086.

Pooler, M.R. and P.W. Simon. 1994. True seed production in garlic. Sexual Plant Reprod. 7:282-286.

Rabinowitch, H.D. 1990. Physiology of flowering, p. 113-134. In: H. D. Rabinowitch and J.L. Brewster (eds.). Onions and allied crops. vol. 1. CRC Press, Boca Raton, Fla.

Reeves, P. H. and G. Coupland. 2000. Response of plant development to environment: Control of flowering by daylength and temperature. Current Opinion Plant Biol. 3:37-42.

Roberts, R.H. and B.E. Struckmeyer. 1951. Observations on the flowering of onions. Proc. Amer. Soc. Hort. Sci. 58:213-219.

Rosen, C.J. and C.B.S.Tong. 2001. Yield, dry matter partitioning, and storage quality of hardneck garlic as affected by soil amendments and scape removal. HortScience 36:1235-1239.

Takagi, H. 1990. Garlic Allium sativum L., p. 109-146. In: H.D. Rabinowitch and J.L. Brewster (eds.). Onions and allied crops. vol. 3. CRC Press, Boca Raton, Fla.

van Kampen, J. 1970. Shortening the breeding cycle in onions. Mededlingen Proefstation voor de Groenteteelt in de Vollegrond, Alkmaar, the Netherlands 51:1-72

Yamasaki, A., K. Tanaka, M. Yoshida, and H. Miura. 2000. Effects of day and night temperatures on flower-bud formation and bolting of Japanese bunching onion (Allium fistulosum L.) J. Jpn. Soc. Hort. Sci. 69:40-46.

Zemah, H. 2001. Effect of temperature on development and flowering of Allium aflatunense (in Hebrew). MSc thesis. Hebrew Univ. Jerusalem. 